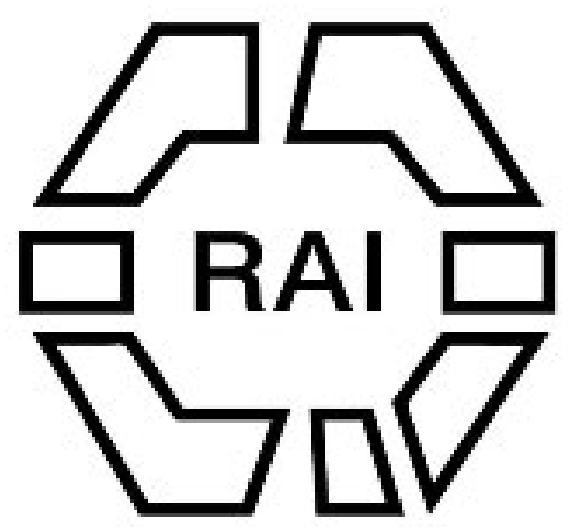

[Notes on Exhibitions of Photographs]

Author(s): E. Desor, A. W. Franks, J. Park Harrison and Morton Allport

Source: The Journal of the Anthropological Institute of Great Britain and Ireland, Vol. 3 (1874), pp. 174-178

Published by: Royal Anthropological Institute of Great Britain and Ireland

Stable URL: http://www.jstor.org/stable/2841304

Accessed: 14/06/2014 06:27

Your use of the JSTOR archive indicates your acceptance of the Terms \& Conditions of Use, available at http://www.jstor.org/page/info/about/policies/terms.jsp

JSTOR is a not-for-profit service that helps scholars, researchers, and students discover, use, and build upon a wide range of content in a trusted digital archive. We use information technology and tools to increase productivity and facilitate new forms of scholarship. For more information about JSTOR, please contact support@jstor.org. 
From the Society.-Mémoires de la Société d'Ethnographie, tome xii, No. 63, 1872 ; Revue Orientale et Americaine, vol. iv, 1860.

From the Author.-Rapport Annuel, Société d'Ethnographie, 1865 ; Sur la Géographie et l'Histoire de la Corée, 1868; Archives Paleographiques, 1869 ; De l'Origine du Langage, 1869; De la Méthode Ethnographique, 1872; Des Affinités du Japonais. By Léon de Rosny.

From Dr. J. Oppert.-Bulletin de l'Athénée Oriental, Nos. 13-19, 1869.

From the Author.-Documents Inédits sur l'Empire des Incas, 1861. By Chas. de Labarthe.

From the Editor.-La Revue Scientifique, Nos. 45 and 46.1873.

From the Ediror. - The Food Journal for May, 1873.

From the Institution.-Jonrnal of the Royal Institution of Cornwall, No. 14, 1873.

From the Society.-Procéedings of the Literary and Philosophical Society of Liverpool.

From the AUrHor.-Della Stirpe che ha popolata l'antica necropoli alla Certosa di Bologna. By Prof. Comm. Luigi Calori.

From the Association.-Journal of the East India Association, vol. vi, No. 4.

From the Society.-Archivio per l'Anthropologia e la Etnologia, vol. iii, No. 1.

From the Society of Arts and Sciences, Batavia.-Verhandelingen, vols. xxxiv, xxxv, and xxxvi ; Tijdschrift, vol. xviii, Nos. 2, 5, and 6, vol. xx, No. 1 ; Notulen, vol. viii, 1870, vol. x, Nos. 1, 3, 1872.

From the SocietY.-Correspondenz Blatt, No. 4, April, 1873.

From the Instimution.-Journal of the Royal United Service Institution, vol. xvii, No. 71 .

From the EdTor. - The Spiritualist for May 15th, 1873.

From the Editor. - Nature (to date).

\section{For the Museum.}

From the Royal Socie'ry of Tasmania.-Two casts from Skulls of Tasmanians, two masks of Tasmanians, six stone implements, and six sheets of photographs of Tasmanians.

The following exhibitions took place.

1. Photograph of prehistoric objects found at Krasnojarsli, on the Yeni Sei, Siberia, accompanied by the following letter from M. E. Desor to Sir John Lubbock, Bart.

Mon cher Monsieur Lubbock, Neuchâtel, 29 Avril, 1873.

Je suis heureux de trouver une occasion de me rappeler à votre bon souvenir en vous adressant aujourd'hui, sous bande, une épreuve 
photographique, représentant quelques antiquités, qui ne sont pas moins remarquables par leur caractère particulier que par leur origine. Ce sont des objets en bronze provenant des bords du Jenisseï. Un heureux hasard m'a mis en possession de ces curieux objets. Voici de quelle manière :

Un ancien élève de notre académie, ayant été placé comme instituteur chez un riche propriétaire de mines d'or, s'est souvenu, au fond de la Sibérie, de quelques leçons de géologie et d'antiquité préhistorique qu'il avait reçues à Neuchâtel. Ayant rencontré à Krasnojarsk un ingénieur russe qui avait les mêmes goûts, celui-ci lui confia la collection qui est représentée sur la feuille photographique. Les objets y sont figurés au tiers de leur grandeur. Vous remarquerez en outre, que ceux du compartiment inférieur sont ornés de figures d'animaux, dont quelques uns sont très reconnaissables, entr'autres le bouquetin sur la pique à gauche, la tête de loup sur le couteau placé longitudinalement et avec anse, puis quatre dessins d'élans superposés tres-frustes, mais cependant très reconnaissables sur le second couteau à droite. Outre cela, ce qu'il y a de plus remarquable, c'est la figure de lionne ou de tigre, qui se trouve à gauche en haut. Je ne saurais, pour ma part, y voir autre chose qu'un grand carnassier ou un animal fantastique, tandis que ces Messieurs de Russie seraient plutôt tentés d'y voir un écho du mammouth, à cause de la trompe, qui fait suite au museau. Quoi qu'il en soit, ces objets attestent une culture plus avancée que celle de nos palafittes ou constructions lacustres. Reste à savoir maintenant, quelles sont leurs affinités. Ils ne sont évidemment pas chinois; ils ne sont pas non plus hindous. Seraient-ils par hasard mongoles ou persans, ou se rattacheraient-ils à quelque civilisation du Touran? C'est ce qu'il vous sera facile de décider au moyen de vos magnifiques collections du Musée Britannique. J'ajoute que ces objets ont été recueillis des pâtres tartares qui les ramassent à la surface du sol, en faisant paître leurs troupeaux dans la steppe. Ils ne sont pas non plus sans analogies avec les objets que Pallas décrit, comme faisant partie du mobilier des anciennes tombes qu'il rencontra sur les bonds du Jenisseï.

Il est incontestable, que ces objets sont d'un grand intérêt pour la paléeethnologie. Les Tartares actuels n'ont aucune tradition sur ces anciens débris, pas plus que les Indiens n'en possèdent sur les anciennes populations des Mounds. Tout ceux qui se sont occupés de ces chuses, à commencer par Pallas, sont d'accord à les attribuer à un peuple disparu. Quel était ce peuple? C'est ce qu'il s'agit d'examiner en se guidant sur ces débris. On se demande involontairement, s'il n'y a pas lieu de faire intervenir ici l'ancien peuple plus ou moins légendaire des Tschoudes, dont le souvenir s'est conservé, paraît-il, dans toutes les traditions de l'Asie orientale, et qui aurait même des échos jusque vers le Nord de l'Europe. Ne serait-ce point, en particulier, le même peuple auquel nos collègues de la Scandinavie sont disposés à attribuer quelque influence sur les anciennes civilisations scandinaves?

Quoi qu'il en soit, il y a une question qui se pose; c'est celle-ci : 
Peut-on admettre qu'une civilisation aussi avancée que celle qui est attestée par les instruments dont je vous transmets la photographie, ait pu se développer spontanément dans des conditions climatériques, comme celles de nos jours, où la température descend chaque année au-dessous du point de congélation du mercure (au mois de Janvier dernier il y a eu $40^{\circ}$ R.) ? Cela nous paraît bien difficile, à moins qu'on ne fasse intervenir l'attrait tout puissant des mines et des lavages d'or, qui constituent encore anjourd'hui la principale raison d'être des colonies sibériennes.

J'ai bien regretté de n'avoir pas eu le plaisir de vous rencontrer aux congrès de Bologne et de Bruxelles. Je m'étais promis d'aller faire une apparition en Angleterre ce printemps. Mais je suis empêché par l'obligation, qui m'est imposée, de visiter l'exposition de Vienne. Aurais-je peut-être le bonheur de vous y rencontrer? Je compte y être à la mi-Juin.

En vous priant d'agréer et de faire agréer à Madame Lubbock l'assurance de mes respects, je demeure,

Votre dévoué,

E. Desor.

2. Photographs of skulls and objects from the Caucasus. By Mr. A. W. Franks.

The photographs were exhibited by permission of Miss Smirnoff, and had been sent to England by Mr. Michael Smirnoff, attached to the "Chancellerie," of the Grand Duke Michael, Viceroy of the Caucasus; they represented various objects discovered in a cemetery called Sainthavro, at Mjhet, in Ossetia, and were accompanied by an account from which the following particulars are extracted :-

"The tombs are similar to those at Kertch, but less deep; we opened twelve of them in three days; some appeared to be of Semitic origin, others Sassanian, and others uncertain. In the latter we discovered the skulls of which photographs are transmitted; they are of the same elongated type that has been found at Kertch, and described by M. Baer. The scarabæoid intaglio of Egyptian style, which is made of cornelian, was found in a Semitic tomb, on the stones of which Hebrew or Phœnician inscriptions have been found. The ornaments were discovered in various tombs, together with Roman coins ; in one instance a glass finger-ring was found, and a vial with the attributes of Hercules. Other vials with attributes of various classical divinities were found. In a tomb of the Sassanian period, I found a very fine narrow bottle of lilac glass. Over the Sassanian tombs are placed stones, reminding one of dolmens in their arrangement. The tombs are separate, and do not appear to have any relation with each other. The large inscription, of which I send a photograph, was on a Semitic tomb. To the north of Mjhet are the traces of a Jewish colony, at a place called Aceldama ; this colony is anterior to the Christian era, and the legends say that it dates from the captivity in Babylon. The Caraites of the Crimæa claim the same antiquity. In the Crimæa is a trogloditic town, inhabited by them, but 
abandoned in 1868; and a similar town, also abandoned, called Oupliss Tzihe, is on the Koura, the river on which Tiflis is built. The mountaineers still dwell in towers similar to the Nuraghis of Sardinia."

3. Mr. J. Park Harrison exhibited photographs and a wooden implement from Easter Island, in the South Pacific, styled by natives "rapa," which is the name of the island itself, as well as that of Oparo, a smaller one two thousand miles to the west.

He said that the form of the rapa was something like a doublebladed paddle, spade-shaped at one end, with a long round handle, ornamented near to the upper end with a bulbous blade, beyond which the handle projects $4 \frac{1}{4}$ inches, with a stop or flange (like what is often found at the end of harpoons and other weapons in the Pacific and coasts of America), about two inches from the extremity.

The implement is now only used in dances, but may have originally have been a steering paddle, grasped by the left hand of the native navigator, whilst a cord of twisted hair or sinnet was held in the other hand, or secured to some part of the vessel.

Some of the ancestors of the Easter Islanders, according to their tradition, arrived from the west in a vessel of considerable size, which must have been carried to their shores by the drift current which still supplies them with wood. Such vessels, and consequently their equipments, would be of no service to the natives of an island so entirely cut off from the rest of the world, and so the rapas losing their original use, were applied to another purpose-perhaps commemorative of the adventurous voyage of the people from whom they were derived. The three which are sculptured on the back of the great stone statue in the British Museum may, in like manner, have a votive meaning.

The canoes or piroques of the islanders, as described by early voyagers, were very small and were formed of pieces of drift wood sewn together with sinnet.

The lower blade of the rapa is ornamented about half-way down, on both faces, with two narrow arches or semi-circles cut in relief. Their interior curves are carried down the centre of the spade-like blade, and terminate on the handle of the rapa an inch or so below the blade. The exterior curves are carried down the sides, and end in circular ornaments or bosses at the corners of the blade.

It did not suggest itself that the ornaments on the rapa might be symbolic, until the remarkable series of New Ireland paddles, collected and arranged by Colonel Lane Fox (some with heads in which elongated ears are conspicuous, and others with mere typical indications of the human face), supplied analogues which seemed to render it almost certain that the arches, centre ridge, and side ornaments on the blades of the rapas symbolised the peculiar eyebrows, nose, and elongated ears, with discs in the lobes, which are found in the stone statue above referred to, and on the rapas sculptured on it, which have distinctly formed eyes and mouths.

Only two other instances have been yet met with of heads, or 
portions of the features of the human face upon paddles, besides those already alluded to in New Ireland, and these rapas from Easter Island. One is a painted paddle in the model of a Nile boat of the dead, in the Egyptian gallery of the British Museum, where the eyes and eyebrows on the blade of the steering paddle are symbols of Osiris, or the sun. Mr. Tylor mentioned that "eyes" are often painted on vessels in the North-Pacific. It is curious that elongated ears and double-bladed paddles are also found in the same locality. The other is tu be seen in the Christy Museum, on a clubpaddle from the Solomon Islands. Here, as in the case of the wooden rapa from Easter Island, part of the features only are in relief.

There are several rapas of different sizes in the Christy Museum, all with the same ornamentation.

Mr. E. B. TyLor remarked on the interest attaching to the paddle exhibited as an example of the disappearance, under unfavourable circumstances, of an art once flourishing. He considered the resemblances between the Easter Island and the Egyptian paddle as to form, decoration with faces, etc., as merely due to independent similar invention under similar conditions.

4. Six photographs and two casts of skulls, and two masks of native Tasmanians, and stone implements, were exhibited, the gift to the museum of Mr. Morton Allport.

In a letter to the Secretary, Mr. Allport said,

"The parcel contains two casts of faces of Tasmanian aborigines taken after death; two casts of skulls of Tasmanian aborigines, from the Lake District on the high central plateau of the island; six stone implements of Tasmanian aborigines, and a number of photographs of Tasmanian natives.

"The stone implements are of the rudest make, but are frequently met with near old camping places and shell mounds, often very far from the parent rock. In one locality, on the high table-land in the centre of Tasmania, large numbers of these rough implements appear to have been manufactured, as chips of the rock, knocked off so long ago as to present weatherworn surfaces, abound and cannot otherwise be accounted for.

"Many of the old residents in the country assure me they have frequently seen natives using these stones, both for skinning animals and for cutting notches in the thick bark of the eucalypti, while climbing. The stones were invariably grasped in the hand, never fixed in any kind of handle. Some few have been found much larger than the specimens now sent."

The following paper was read by the author :

On the Egyptian Colony and Language in the Caucasus, and
its Anthropological Relations. By Hyde Clarke. Herodotus, in his second book, is very circumstantial and very 